\title{
BURNOUT LEVEL OF TOURIST GUIDES: AN EMPIRICAL STUDY
}

\author{
Yalçın Arslantürk ${ }^{1}$ \\ M. Tuna Üner ${ }^{2}$
}

\begin{abstract}
Burnout syndrome affects the employee performance and therefore service quality of a company. Especially, when it comes to tourism-related labour, in this case tour guides, pivotal interface in tourism industry, it is of great importance to examine the extent of burnout in an occupation which not only depends on physical strength but intellectual as well.

Although the subject of burnout has well been documented and examined in other occupations, to date, there has been no single study into the burnout level and the concept of burnout with specific reference to tour guides. On the other hand, since the issue of Law on Tourist Guide Occupation in 2012, tour guides, recognized by TUREB (Union of Tourist Guides' Chamber) have become an obligatory part of package tours. This stipulates that tourist guides have to be licenced subsequent to training programs and packaged tours have to be attended by licenced tourist guides. This study was conducted to determine the burnout level of tourist guides. Following a comprehensive examination of the literature on burnout syndrome and tour guiding, this paper goes on with the method part. As data collection instrument, Copenhagen Burnout Inventory has been employed in this study. The number of the participants is 248 licenced tourist guides registered in Ankara Tourist Guides' Chamber. The data gathered were analysed through statistical software packages and the results indicated that emotional exhaustion, depersonalization and personal accomplishment in terms of sub-dimensions were found to have lower levels of burnout. In addition, rather than the personality factors, the burnout level was found out to be affected by work-related factors. Hence, it is suggested that organizational and job-related measures should be taken in order to decrease the level of burnout in tourist guides.
\end{abstract}

Key words: occupational burnout, tourist guide, Copenhagen Burnout Inventory

\section{INTRODUCTION}

Tourism has been one of the most lucrative and largest sectors across the world for the last six years. Despite the economic crises, international arrivals are on the increase and reached from $25 \mathrm{~m}$ to $278 \mathrm{~m}, 528 \mathrm{~m}$ and $1087 \mathrm{~m}, 1133 \mathrm{~m}$ and $1184 \mathrm{~m}$ in $1950,1980,1995$, 2013, 2014 and 2015 from respectively (United Nations World Tourism Organization [UNWTO], 2016). Parallel to this increase, the number of tourism employees are going up as well. Since tourism is a sector with high labour content, the quality of tourism product is two folds; that is, goods offered and service quality, which is totally dependent on the employee and customer interaction. According to Weiermair and Bieger (2005) "The quality of the tourism product is therefore not only dependent on

\footnotetext{
${ }^{1}$ Gazi University, Faculty of Tourism, Department of Travel Management and Tour Guiding arslanturk@gazi.edu.tr

${ }^{2}$ Specialist, Tourist Guide, tunauner@gmail.com
} 
the quality of the natural resources tourists ask for, but on the quality of the people working in the tourism industry" (p.40). This being the case, tourist guides are an indispensable part of the tourism system and they perform tourism-related labour where interaction becomes very evident and reaches to the top. Therefore, the perceived quality of tourist guides by customers has a lot to do with the character of guide and customer interaction. Despite the fact that travels in ancient times could not be regarded as a part of leisure, tour guides have existed since then. Travels in ancient times were a part of need or obligation to survive and in this sense first travels set out to labour, find food or to migrate due to harsh climate conditions. For this reason, the word "travel" stems from the French word " travailler", which means "to work, to labour" (Pond, 1993). The main function of guides was "path finding" in ancient times (Cohen, 1985). Since the emerge of mass travel in 19th century, the roles of guides ranged from "path finder" to "educator" and "cultural representative" (Holloway, 1981; Cohen, 1985; Pond, 1993; Black and Weiler, 2005).

\section{TOURIST GUIDING}

Tourist guides hold a special place in tourism systems, especially in Turkey. Considering the travel agencies, they are an indispensable feature of the supply-side stipulated by "Law on Tourist Guide Occupation numbered 6326" and since then the National Union of Tourist Guides' Chamber (TUREB) has the control over tour guiding profession across the country. In short, the law mandates that packaged tours have to be accompanied by licenced tourist guides. Owing to this, the special and mandatory positions of tourist guides are underlined once again. Tourist guides are service providers for visitors (Pond, 1993). They act as an interface. They are the front-line people to such an extent that they are very effective on the general success of the services with reference to satisfaction (Ap and Wong, 2001, p.521). Irrespective of the slight differences in content, World Federation of Tourist Guide Associations (WFTGA) makes the most comprehensive and internationally-adopted definition; "[a tourist guide is] a person who guides visitors in the language of their choice and interprets the cultural and natural heritage of an area which person normally possesses an area-specific qualification usually issued and/or recognised by the appropriate authority" (WFTGA, 2014).

Although tourist guides and tour guiding are of great contributors to tourism services, compared to other field in tourism, empirical research into tour guiding is relatively lower in number. Rather than an academic focus of study, "the tour guiding profession has been the "Cinderella" of the tourism industry: attractive, useful, but often neglected" (Mak, et al, 2011). On the other hand, it will not be wrong to hold that the number of academic studies into tour/tourist guiding is relatively lower in number and these studies are combined with marketing and management aspects of tour guiding (e.g. Batman, 2003; Tosun and Temizkan, 2004; Demirkol and Ekmekçi, 2005; Ahipaşaoğlu, 2001; Yarcan, 2007; Yazıcıoğlu et al., 2008; Korkmaz et al., 2010; Çetin 
and Kızılırmak, 2012; Kaya and Özhan, 2012; Kozak and Yetgin, 2013; Köroğlu, 2013; Güzel et al. 2013; Tetik, 2015).

According to the data of June 2016, the number of registered tourist guides at TUREB is 9746 (TUREB, 2016). To date, there has been no study into the burnout syndrome among tourist guides. Owing to the indispensible position of tourist guides in tourism system of Turkey, it is of great benefit that the effect of burnout syndrome among tourist guides should be examined. In this context, the outcome of this study is thought to contribute to the literature of tourist guiding with special emphasis on Turkish tourism system and Turkish tourist guides. This makes up one of the motivations of this paper and as such this study sets out to perform and empirical study in order to determine the burnout level of tourist guides.

\section{Burnout Syndrome}

The term burnout entered in the literature of psychosocial studies in the $1980 \mathrm{~s}$ by Freudenberger (1983) and Maslach (1982). Having independently studied on the concept of burnout, they examined the responses of voluntary-workers who worked with the citizens with lower social status. Late 1970s were the years in which, unlike the industrial workers, little focus was given to those interacting in human services such as nurses and teachers Nowadays, the term burnout is not merely well recognized in psychosocial research but a well-known and popular word among human service workers in a number of countries as well (Kristensen et al., 2005).

Burnout syndrome can be defined as a form of unproductive reactions that individuals reveal when faced with stressors and/or demands of the workplace (Shirom, 1989). According to Maslach (1982), job burnout consisted of three dimensions; emotional exhaustion described as lack of energy, depersonalization described as detachment from co-workers and the organization, and decreased personal accomplishment defined as negative self-evaluations and low self-confidence (Pines \& Maslach, 1980). The main effect of burnout is usually considered as emotional exhaustion which may give rise to the sentiment that an individual is not efficient in his position in the organization any longer (Shirom, 2003). When an individual undergoes emotional exhaustion, cynicism emerges as an expected result and this leads an individual to a self-protective mode and to a distance from colleagues (Maslach \& Leiter, 1997). Therefore, in order to prevent and/or minimize the effects of burnout, organizations should be prepared to focus on offering "an environment with a sustainable workload, rewards and recognition for good work, and a sense of community among employer and employees... [in this way] people will find meaning and value in their work" (Angerer, 2003, p. 105).

\section{The Copenhagen Burnout Inventory (CBI)}

The Copenhagen Burnout Inventory (CBI) is a research instrument that is made up of three dimensions; personal burnout, work-related burnout, and client-related burnout. 
CBI was evolved through a five year longitudinal research called the Project on Burnout, Motivation, and Job Satisfaction (PUMA) in Denmark on 1,914 human service workers in order to examine the prevalence, distribution, causes, and consequences of burnout. For example, questions of personal burnout on the CBI are; (a) How often do you feel tired? (b) How often are you physically exhausted? (c) How often are you emotionally exhausted? (d) How often do you think: "I can't take it anymore"? (e) How often do you feel worn out? and (f) How often do you feel weak and susceptible to illness? (Kristensen et al., 2005).

\section{Why CBI?}

The Maslach Burnout Inventory (MBI) has a monopoly power in empirical studies on burnout and is implemented nearly $90 \%$ of the papers related to burnout (Schaufeli and Enzmann;1998, p. 71). However, Kristensen et al. (2005) developed a new burnout inventory claiming that theirs outdoes MBI in several aspects. To start with; the scales of CBI differentiated well among occupational groups and statistical analyses showed very high reliability and validity for CBI. Besides, CBI has been used in many countries and translations into eight languages are available free of charge. As a criticism to MBI, Kristensen et al. (2005) postulate that measuring burnout syndrome by MBI is restricted to specific parts of labour and client relations; that is to say, MBI might not be implemented in all aspects of employment contexts. Secondly, they claim that MBI does not necessarily measure the nature of burnout concept as perceived. Then, some of the items used by MBI may lead to some argumentative responses, thus causing respondents' bias. Finally, MBI is protected by copyrights and is available only under commercialized contexts, unlike CBI (Kristensen et al. ,2005). Considering these aforementioned facts, this study employs a more comprehensive and relatively contemporary Copenhagen Burnout Inventory.

\section{METHOD}

The study is of descriptive nature. Descriptive research is used to describe characteristics of a population or phenomenon being studied. It does answer questions about how/when/why the characteristics occurred. Rather it addresses the "what" question (Kurtuluş, 1996). This paper uses questionnaire forms; the mostly-employed technique of data collection in descriptive studies due to low cost, time allocation for respondent to answer based on their pace and provision of anonymity (Muijs, 2004). As a data collection tool, questionnaires are considered suitable instruments to measure variables with multiple choices, not-easily observable variables and when the presence of the researcher could affect the responses of the participants (Nardi, 2003).

Convenience sampling was determined in sampling the population. In a 5-point Likert scale ranging from 5 (definitely agree) to 1 (definitely not agree), 400 questionnaire forms were delivered to Ankara Tourist Guides' Chamber, operating under the 
authority of TUREB. However, due to such reasons as erroneous coding, half-coding and low presence of tourist guides in high-seasons, only 248 forms were deemed appropriate to be analyzed through the Statistical Program for the Social Sciences (SPSS) software. Confidence level was taken as $\% 95$ or $\mathrm{p}<0.05$, which is accepted as level of confidence used in social sciences (Black, 1999; Vogt, 2007).

\section{The Model of the Study}

Figure 1 shows the variables used within the scope of the study. According to the model, the variables under consideration are gender, duration of employment, age and nationality of the tourist guided along with the dimensions of CBI, which are personal burnout, work-related burnout and client-related burnout.

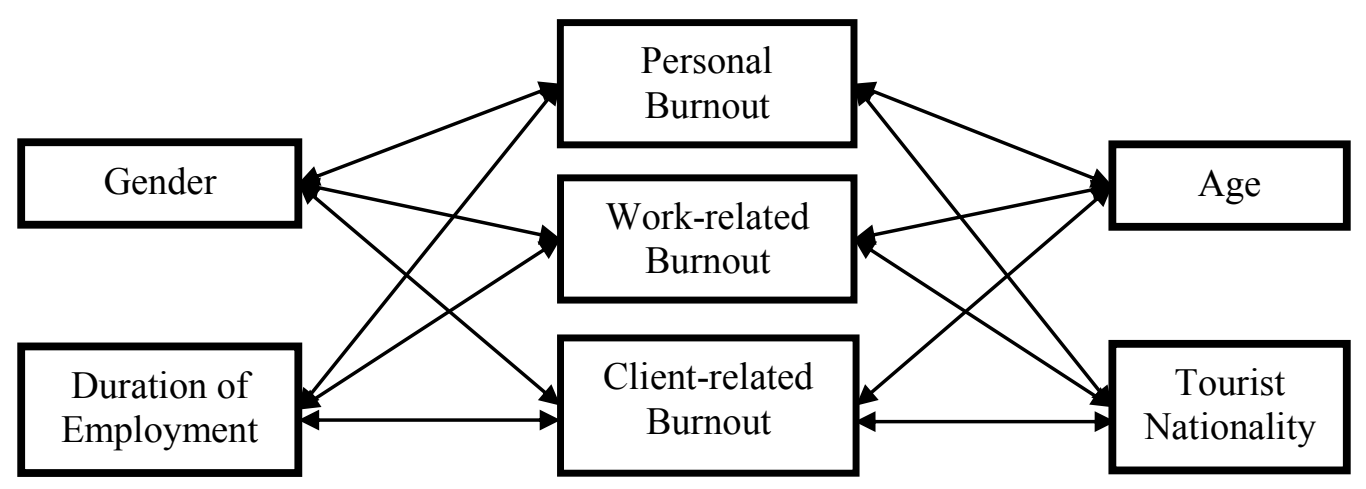

Fig. 1. Model of the Study

\section{The Objective and Hypotheses}

There has been no study into burnout level of tourist guides to date in the literature review. This study sets out to examine the burnout level of tourist guides in terms of different variables. The variables under consideration are age, gender, duration of employment and finally nationality of tourists guided. More specifically, whether there are statistically significant differences is sought after among the variable under consideration and the dimensions of CBI. It is deemed significant to examine the burnout level and differences by the variables under consideration in that there will be suggestions based on the findings and the problems detected.

High turnover rate in service sector, intense face-to-face interaction, flexible work hours, workload may lead to burnout syndrome (Kristensen et al.,2005). Within this perspective, since the profession of tourist guiding entails the comprehensive management and implementation of the package tour marketed by travel agencies, problems that might be encountered during the delivery of tour will have to be handled by tourist guides and this intense workload and face-to-face interaction could bring 
about a notion of burnout syndrome among tourist guides. In order to serve the purpose of the study, the following hypotheses have been postulated.

H1: There is a statistically significant difference between the burnout level of tourist guides and gender.

H1a: There is a statistically significant difference between the personal burnout level of tourist guides and gender.

H1b: There is a statistically significant difference between the work-related burnout level of tourist guides and gender.

H1c: There is a statistically significant difference between the client-related burnout level of tourist guides and gender.

As for the nationality of the groups guided;

$\mathrm{H} 2$ : There is a statistically significant difference between the burnout level of tourist guides and the nationality of the groups guided.

$\mathrm{H} 2 \mathrm{a}$ : There is a statistically significant difference between the personal burnout level of tourist guides and the nationality of the groups guided.

$\mathrm{H} 2 \mathrm{~b}$ : There is a statistically significant difference between the work-related burnout level of tourist guides and the nationality of the groups guided.

$\mathrm{H} 2 \mathrm{c}$ : There is a statistically significant difference between the client-related burnout level of tourist guides and the nationality of the groups guided.

As for age;

H3: There is a statistically significant difference between the burnout level of tourist guides and age.

$\mathrm{H} 3 \mathrm{a}$ : There is a statistically significant difference between the personal burnout level of tourist guides and age.

$\mathrm{H} 3 \mathrm{~b}$ : There is a statistically significant difference between the work-related burnout level of tourist guides and age.

$\mathrm{H} 3 \mathrm{c}$ : There is a statistically significant difference between the client-related burnout level of tourist guides and age.

As for the nationality of the duration of employment;

H4: There is a statistically significant difference between the burnout level of tourist guides and duration of employment.

$\mathrm{H} 4 \mathrm{a}$ : There is a statistically significant difference between the personal burnout level of tourist guides and duration of employment.

H4b: There is a statistically significant difference between the work-related burnout level of tourist guides and duration of employment.

H4c: There is a statistically significant difference between the client-related burnout level of tourist guides and duration of employment.

\section{Reliability Analysis}

Reliability analysis performs the function of measuring the internal consistency of the items used in a scale as well as the correlation between the items (Gökçe, 1992). The 
reliability of the scale used in this paper has been determined using Cronbach's Alpha $(\alpha)$. The criteria used in the evaluation of the reliability analysis are that the scale is not reliable if the coefficient is between $0.00 \leq \alpha<0.40$, low level of reliability if $0.40 \leq \alpha$ $<0.60$, and moderate level of reliability if $0.60 \leq \alpha<0.80$ and finally high level of reliability if $0.80 \leq \alpha<1.00$ (Özdamar, 2002). Given this, Table 1 reports the findings of reliability analysis and it is seen that the coefficient, on the whole, is 0.847 , which indicates high level of reliability.

Table 1. Internal Reliability Coefficients $(\alpha)$ of CBI

\begin{tabular}{lcc}
\hline Dimensions & Number of Items & $\boldsymbol{\alpha}$ \\
\hline Personal & 6 & 0.848 \\
\hline Work-related & 7 & 0.845 \\
\hline Client-related & 6 & 0.848 \\
\hline \multicolumn{1}{c}{ rotal } & $\mathbf{1 9}$ & $\mathbf{0 . 8 4 7}$ \\
\hline
\end{tabular}

\section{FINDINGS}

Table 2 reports some of the demographic information used in this study. Only the variables used with respect to the objective of the paper have been covered in Table 1 . Given this, the majority of the participants hold a university degree with $61.69 \%$ and $70.6 \%$ of the participants are male. On the other hand, in terms of the groups guided, the majority of the participants $(77.02 \%)$ guide foreign groups. When the variable "duration of employment" is taken into consideration, those with 0-4 and 20+ years of experience are the ones with the highest majority, $26.21 \%$ and $26.21 \%$, respectively. Considering the age variable, the majority of the participants are within the age ranges of $25-34$, with a rate of $41.94 \%$.

Table 2. Demographics of the Participants

\begin{tabular}{|c|c|c|c|c|c|c|c|}
\hline \multirow{8}{*}{ Education } & & $\mathbf{n}$ & $\%$ & \multirow{8}{*}{$\begin{array}{l}\text { Duration of } \\
\text { Employment }\end{array}$} & & $\mathbf{n}$ & $\%$ \\
\hline & High School & 20 & 8.06 & & $0-4$ & 65 & 26.21 \\
\hline & Pre- & & & & & & \\
\hline & Bachelor's & 33 & 13.31 & & $5-9$ & 56 & 22.58 \\
\hline & Bachelor's & 153 & 61.69 & & $10-14$ & 31 & 12.5 \\
\hline & Master's & 34 & 13.71 & & $15-19$ & 31 & 12.5 \\
\hline & $\mathrm{PhD}$ & 8 & 3.23 & & $20+$ & 65 & 26.21 \\
\hline & Total & 248 & 100 & & Total & 248 & 100 \\
\hline \multirow{4}{*}{ Gender } & & $\mathbf{n}$ & $\%$ & \multirow{4}{*}{ Age } & & $\mathbf{n}$ & $\%$ \\
\hline & Male & 175 & 70.6 & & $20-24$ & 7 & 2.82 \\
\hline & Female & 73 & 29.4 & & $25-29$ & 52 & 20.97 \\
\hline & Total & 248 & 100 & & $30-34$ & 52 & 20.97 \\
\hline
\end{tabular}




\begin{tabular}{|c|c|c|c|c|c|c|}
\hline \multirow{6}{*}{$\begin{array}{c}\text { Nationality } \\
\text { of Tourist }\end{array}$} & & $\mathbf{n}$ & $\%$ & $35-39$ & 26 & 10.48 \\
\hline & Turkish & 42 & 16.94 & $40-44$ & 41 & 16.53 \\
\hline & Foreign & 191 & 77.02 & $45-49$ & 27 & 10.89 \\
\hline & Equal & 15 & 6.05 & $50-54$ & 21 & 8.47 \\
\hline & Total & 248 & 100 & $55+$ & 22 & 8.87 \\
\hline & & & & Total & 248 & 100 \\
\hline
\end{tabular}

Table 3 presents some of the basic statistics such as number of items, averages of the items for each dimensions and the standard deviation. According to Table 3, the average burnout level of the respondents (tourist guides) averages 2.43 out of 5 - since the scale is a 5-point Likert scale. This shows that tourist guides who took part in the study are moderately affected by burnout syndrome. Talking specifically about the dimensions, the average of work-related burnout is lightly higher than the average of the other two dimensions.

Table 3. Basic Descriptive Statistics on CBI

\begin{tabular}{lccl}
\hline Dimensions & Number of Items & $\overline{\mathbf{X}}$ & s.d. \\
\hline Personal & 6 & 2.35 & 0.802 \\
\hline Work-related & 7 & 2.56 & 0.91 \\
\hline Client-related & 6 & 2.38 & 0.88 \\
\hline Total & 19 & 2.43 & 0.864 \\
\hline
\end{tabular}

\section{Tests of Hypotheses}

In this part of the study, the results of $t$ test are presented. The variables under consideration as shown in Figure 1 are age, gender, duration of employment, and nationality of the groups guided. In the $t$ test performed, if the significance level (p) is lower than $(\alpha)=0.05$; that is to say; $\mathrm{p}<0.05$, H1 hypothesis is supported, otherwise, rejected. In other words, it is concluded that there is no statistically significant difference between the scores of the variables under consideration.

Table 4 indicates the results of $t$ test means and standard deviation by gender. According to the $t$ test results, there is only a statistically significant difference between the personal burnout of tourist guides and gender $(\mathrm{p}<0.01)$. Specifically, average burnout level of female tourist guides (2.598) is higher than that of male tourist guides (2.252) and this difference is statistically significant. On the other hand, no statistically significant difference has been found out in other dimensions of the CBI.

Table 4. Results of $t$ test, Means and Standard Deviation by Gender

\begin{tabular}{lcccccc}
\hline & Gender & $\mathbf{n}$ & $\bar{X}$ & s.d. & t & p \\
\hline Personal & Male & 175 & 2.2524 & 0.765 & 3.149 & $0.002 * *$ \\
\cline { 2 - 6 } & Female & 73 & 2.5982 & 0.83971 & & \\
\hline
\end{tabular}




\begin{tabular}{lcccccc}
\hline Work-related & Male & 175 & 2.5208 & 0.88515 & 1.11 & 0.268 \\
\cline { 2 - 6 } & Female & 73 & 2.6614 & 0.96466 & & \\
\hline Client-related & Male & 175 & 2.3752 & 0.88831 & 0.142 & 0.887 \\
\cline { 2 - 6 } & Female & 73 & 2.3927 & 0.86619 & & \\
\hline
\end{tabular}

$* * \mathrm{p}<0.01$

Table 5 reports results of one-way variance (ANOVA) for the dimensions of CBI by tourist nationality. In the dimension of "work-related" burnout, the means of "Turkish", "Foreign" and "Equal" groups are 2.836, 2.473 and 2.923, respectively and there is a statistically significant difference by tourist nationality $(\mathrm{p}<0.05)$. As a result of Tamhane's T2 post-hoc test, this difference stems from all the "Turkish", "Foreign" and "Equal" groups considered.

On the other hand, In the dimension of "client-related" burnout, the means of "Turkish", "Foreign" and "Equal" groups are 2.718, 2.279 and 2.722, respectively and there is a statistically significant difference by tourist nationality $(\mathrm{p}<0.001)$. As a result of Tamhane's T2 post-hoc test, this difference is among all the "Turkish", "Foreign" and "Equal" groups considered.

Table 5. Results of One-Way Variance (ANOVA) for the Dimensions of CBI by Tourist Nationality

\begin{tabular}{|c|c|c|c|c|c|c|c|}
\hline & $\begin{array}{l}\text { Tourist } \\
\text { Nationality }\end{array}$ & n & $\bar{X}$ & sd & $\mathbf{F}$ & $\mathbf{p}$ & $\begin{array}{c}\text { Tamhane's } \\
\text { T2 }\end{array}$ \\
\hline \multirow[t]{4}{*}{ Personal } & Turkish & 42 & 2.4325 & 0.81986 & \multirow{4}{*}{0.897} & \multirow{4}{*}{0.409} & \\
\hline & Foreign & 191 & 2.3202 & 0.80367 & & & \\
\hline & Equal & 15 & 2.5667 & 0.73138 & & & \\
\hline & Total & 248 & 2.3542 & 0.80212 & & & \\
\hline \multirow[t]{4}{*}{ Work-related } & Turkish & 42 & 2.8367 & 0.98246 & \multirow{4}{*}{4.109} & \multirow{4}{*}{$0.018^{*}$} & 2 \\
\hline & Foreign & 191 & 2.4734 & 0.87716 & & & $1-3$ \\
\hline & Equal & 15 & 2.9238 & 0.92403 & & & 2 \\
\hline & Total & 248 & 2.5622 & 0.90957 & & & \\
\hline \multirow{4}{*}{$\begin{array}{l}\text { Client- } \\
\text { related }\end{array}$} & Turkish & 42 & 2.7183 & 0.90053 & \multirow{4}{*}{5.696} & \multirow{4}{*}{$0.004 * *$} & 2 \\
\hline & Foreign & 191 & 2.2792 & 0.8349 & & & $1-3$ \\
\hline & Equal & 15 & 2.7222 & 1.10674 & & & 2 \\
\hline & Total & 248 & 2.3804 & 0.88015 & & & \\
\hline
\end{tabular}

1: Personal 2: Work-related 3: Client-related

Table 6 reports results of one-way variance (ANOVA) for the dimensions of CBI by age. Only in the dimension of "work-related", there is a difference. Average (3.016) burnout level of those with 35-39 years of age is higher than those (2.299) with 30 - 34 years of age and this difference is statistically significant. Tamhane's T2 post-hoc test 
suggests that except for the 35-39 years and 30-34 years, the differences are not statistically significant. As for the other dimensions of CBI, there has been no statistically significant difference found.

Table 6. Results of One-Way Variance (ANOVA) for the Dimensions of CBI by Age

\begin{tabular}{|c|c|c|c|c|c|c|c|}
\hline & Age & $\mathbf{n}$ & $\bar{X}$ & Sd & $\mathbf{F}$ & $\mathbf{p}$ & Tamhane'sT2 \\
\hline \multirow{9}{*}{ Personal } & $20-24$ & 7 & 1.9762 & 0.522 & \multirow{9}{*}{142} & \multirow{9}{*}{0.198} & \\
\hline & $25-29$ & 52 & 2.2853 & 0.77427 & & & \\
\hline & $30-34$ & 52 & 2.3045 & 0.74953 & & & \\
\hline & $35-39$ & 26 & 2.7436 & 0.80585 & & & \\
\hline & $40-44$ & 41 & 2.248 & 0.7756 & & & \\
\hline & $45-49$ & 27 & 2.3086 & 0.80424 & & & \\
\hline & $50-54$ & 21 & 2.4921 & 1.00066 & & & \\
\hline & $55+$ & 22 & 2.4167 & 0.83373 & & & \\
\hline & Total & 248 & 2.3542 & 0.80212 & & & \\
\hline \multirow{9}{*}{$\begin{array}{l}\text { Work- } \\
\text { related }\end{array}$} & $20-24$ & 7 & 2.8367 & 0.67727 & \multirow{9}{*}{2.145} & \multirow{9}{*}{$0.04 *$} & \\
\hline & $25-29$ & 52 & 2.5165 & 0.84783 & & & \\
\hline & $30-34$ & 52 & 2.2995 & 0.82588 & & & 4 \\
\hline & $35-39$ & 26 & 3.0165 & 1.02645 & & & 3 \\
\hline & $40-44$ & 41 & 2.5226 & 0.92395 & & & \\
\hline & $45-49$ & 27 & 2.5556 & 1.04027 & & & \\
\hline & $50-54$ & 21 & 2.8776 & 1.00538 & & & \\
\hline & $55+$ & 22 & 2.4481 & 0.66466 & & & \\
\hline & Total & 248 & 2.5622 & 0.90957 & & & \\
\hline \multirow{9}{*}{$\begin{array}{l}\text { Client- } \\
\text { related }\end{array}$} & $20-24$ & 7 & 3.0714 & 0.3582 & \multirow{9}{*}{3.094} & \multirow{9}{*}{0.44} & \\
\hline & $25-29$ & 52 & 2.4327 & 0.89859 & & & \\
\hline & $30-34$ & 52 & 2.4071 & 0.83131 & & & \\
\hline & $35-39$ & 26 & 2.6218 & 0.9917 & & & \\
\hline & $40-44$ & 41 & 2.0163 & 0.73862 & & & \\
\hline & $45-49$ & 27 & 2.3333 & 1.05409 & & & \\
\hline & $50-54$ & 21 & 2.7619 & 0.86694 & & & \\
\hline & $55+$ & 22 & 2.0606 & 0.61624 & & & \\
\hline & Total & 248 & 2.3804 & 0.88015 & & & \\
\hline$* \mathrm{p}<0,05$ & $: 20-24$ & $2: 25-29$ & $3: 30-34$ & $4: 35-35$ & & $40-44$ & 6: $45-49$ \\
\hline
\end{tabular}

Table 7 reports results of one-way variance (ANOVA) for the dimensions of CBI by age. The results of ANOVA (one-way variance), considering the personal, workrelated and client-related dimensions of $\mathrm{CBI}$, there is no statistically significant difference. 
Table 7. Results of One-Way Variance (ANOVA) for the Dimensions of CBI by Duration of Employment

\begin{tabular}{|c|c|c|c|c|c|c|c|}
\hline & Duration & $\mathbf{n}$ & $\bar{X}$ & sd & $\mathbf{F}$ & p & Tamhane's T2 \\
\hline \multirow{6}{*}{ Personal } & $0-4$ & 60 & 2.375 & 0.73173 & \multirow{6}{*}{1.379} & \multirow{6}{*}{0.242} & \\
\hline & $5-9$ & 61 & 2.3907 & 0.81813 & & & \\
\hline & $10-14$ & 26 & 2.5897 & 0.89223 & & & \\
\hline & $15-19$ & 35 & 2.4 & 0.83646 & & & \\
\hline & $20+$ & 66 & 2.1843 & 0.78399 & & & \\
\hline & Total & 248 & 2.3542 & 0.80212 & & & \\
\hline \multirow{6}{*}{$\begin{array}{l}\text { Work- } \\
\text { related }\end{array}$} & $0-4$ & 60 & 2.5738 & 0.76796 & \multirow{6}{*}{0.177} & \multirow{6}{*}{0.976} & \\
\hline & $5-9$ & 61 & 2.6019 & 0.95942 & & & \\
\hline & $10-14$ & 26 & 2.5165 & 1.00292 & & & \\
\hline & $15-19$ & 35 & 2.6041 & 0.88883 & & & \\
\hline & $20+$ & 66 & 2.5108 & 0.97603 & & & \\
\hline & Total & 248 & 2.5622 & 0.90957 & & & \\
\hline \multirow{6}{*}{$\begin{array}{l}\text { Client- } \\
\text { related }\end{array}$} & $0-4$ & 60 & 2.4861 & 0.81436 & \multirow{6}{*}{1.193} & \multirow{6}{*}{0.314} & \\
\hline & $5-9$ & 61 & 2.5219 & 0.83913 & & & \\
\hline & $10-14$ & 26 & 2.2372 & 0.7545 & & & \\
\hline & $15-19$ & 35 & 2.281 & 1.0047 & & & \\
\hline & $20+$ & 66 & 2.2626 & 0.94238 & & & \\
\hline & Total & 248 & 2.3804 & 0.88015 & & & \\
\hline
\end{tabular}

\section{CONCLUSION AND DISCUSSION}

Burnout syndrome comes out as a result of the interaction between individual and work setting. Behind the interaction as the reasons that lead to burnout might be categorized as those related to individual features, work settings, and the job related ones, as specified in the CPI. Such demographic specifications as age, gender, duration of employment are closely linked to the individual variables in the burnout syndrome .Hence as in this study some demographic variables have been taken into account.

Besides, as for the work setting, as is well known and documented in the related literature, the intense interaction between the customers and the tourism employees, in this case tourists guides, leads the way to burnout somewhat in a swift manner and different from the other sectors with lesser degree of interaction. Take from the aspect of tourist guiding, it is not unjust to hold that the number of studies into tour guiding is scant. Considering the interface functions of tourist guides and their stipulated-by-law position in package tours, tourist guides make up an important portion in tourism work flow. 
This study set out to examine the burnout levels of tourist guides. The variables under consideration were, in short, gender, age, experience and nationality of the groups guided. The results of the analyses conducted suggest that the burnout level of tourist guides averages around 2.5 out of 5 . Hence, it is not wrong to put forward that tourist guides are affected by burnout syndrome in a considerable manner. The results of the hypotheses test show that there is only a statistically significant difference between the personal burnout of tourist guides and gender. H1a hypothesis that there is a statistically significant difference between the personal burnout level of tourist guides and gender is supported $(\mathrm{p}<0.01)$. Considering the nationality of the groups guided, H2b hypothesis that there is a statistically significant difference between the work-related burnout level of tourist guides and the nationality of the groups guided $(\mathrm{p}<0.05)$ and $\mathrm{H} 2 \mathrm{c}$ hypothesis that there is a statistically significant difference between the client-related burnout level of tourist guides and the nationality of the groups guided $(\mathrm{p}<0.01)$ are supported only in the "work-related" and "client-related" dimensions of CBI. Besides, with regard to age variable, $\mathrm{H} 3 \mathrm{~b}$ hypothesis that there is a statistically significant difference between the work-related burnout level of tourist guides and age is supported ( $p<0.05)$. On the other hand, as for the variable of "duration of employment", no statistically significant relationship has been found.

The results suggest that the burnout level of tourist guides is lower than expected. This can be put down to two main facts. First, in Turkey, tourist guiding is usually regarded a part of second employment. Although there is no statistically verified data on this, it is not unjust to claim a number of registered tour guides in Turkey have a main job and perform tour guiding as a second job. For this reason, tour guiding is regarded as a supplementary income. Secondly, according to the official fees announced by TUREB, a daily tour ranges from around $\$ 100$ to $€ 100$ and considering the fact that the minimum wage per month stipulated by law is around $\$ 400$, tour guiding can be regarded as a source of reasonable income, which is a motivation for tourist guides. These two reasons could be influential in explaining the low level of burnout syndrome among registered tourist guides in Turkey. For the future research, it is highly suggested that the number of the respondents should be increased and new variables should be put into use such as whether tourist guiding is the primary or secondary employment.

\section{IMPLICATIONS}

It is of great significance that the notion of burnout should be handles in a holistic approach. In other words, the probable reasons along the probable outcomes should be dealt with specific attention in order to keep the wheels of an organization going in not only efficient but also effective manner. The very first thing that managers bear in mind is that burnout is not a syndrome likely to appear just in one day. Hence, the symptoms of the syndrome might be detected beforehand especially for the experienced tour guides, as the result of this study also suggests. Besides, since tourist guiding is very much dependent on physical strength, the performance of guides could be easily 
affected and the overall satisfaction of the tour participants. In order to decrease the impacts of burnout, individuals and organizations should be knowledgeable about the concept of burnout, the symptoms of it. On condition that this happens, the influence of burnout could be held at the minimum before it undermines the efficient running of the whole organization.

\section{REFERENCES}

1. Ahipaşaoğlu, H.S. (2001). Turizmde Rehberlik. 1. Bask1, Detay Yayıncılık: Ankara.

2. Angerer, J.M. (2003). Job burnout. Journal of Employment Counseling, 40(3), 98107.

3. Ap, J., ve Wong, K. K. F. (2001). Case study on tour guiding: Professionalism, issues and problems. Tourism Management, 22, 551-563.

4. Batman, O. (2003). Türkiye'de profesyonel turist rehberlerinin mesleki sorunlarına yönelik bir araştırma. Bilgi Sosyal Bilimler Dergisi, 5(2), 117-134.

5. Black, R.S.ve Weiler, B. (2005). Quality assurance and regulatory mechanisms in the tour guiding industry: A systematic review. Journal of Tourism Studies, 16(1), 24-37.

6. Black, T.R. (1999). Doing quantitative research in the social sciences. CA: Sage Publications.

7. Cohen, E. (1985). The tourist guide: The origins, structure and dynamics of a role. Annals of Tourism Research, 12(1), 5-29.

8. Çetin, G. ve Kızılırmak, İ. (2012). Türk turizminde kokartlı turist rehberlerin mevcut durumunun analizi. Afyon Kocatepe Üniversitesi İ̈BF Dergisi, 14 (2), $307-$ 318.

9. Demirkol Ş. ve Ekmekçi İ. (2005). Paket Turların Sürdürülebilirliğinde Turist Rehberlerine Etik Bir Bakış", IV. Geleneksel Turizm Paneli, Sakarya, 22 Nisan: 5985.

10. Freudenberger, H.J. (1983). Burnout: contemporary issues, trends, and concerns. In B.A. $\quad$ Farber, (Ed.). Stress and burnout (pp. 23-28). New York: Anchor Press/ Doubleday.

11. Gökçe, B. (1992). Toplumsal Bilimlerde Araştırma. (2.Basım). Ankara: Savaş Yayınlar1.

12. Güzel, F.Ö., Atilla G. G. ve İşler, D. B. (2013). Duygusal Emek ve İşten Ayrrlma Niyeti İlişkisi: Turist Rehberleri Üzerinde Bir Araştırma. Seyahat ve Otel Işsletmeciliği Dergisi, Eylül-Aralık, 10(3): 107- 122.

13. Holloway, J.C. (1981). The guided tour: A sociological approach. Annals of Tourism Research, 8(3), 377-401

14. Kaya, U. ve Özhan, Ç. K. (2012). Duygusal Emek ve Tükenmişlik İlişkisi: Turist Rehberleri Üzerine Bir Araştırma. Çalışma İlişkileri Dergisi, 3 (2), 109 - 130 
15. Korkmaz, S., Temizkan, S.P. ve Temizkan, R. (2010). Profesyonel Turist Rehberliğine Yönelik Zorunlu Hizmet İçi Eğitim Seminerlerinin Pazarlama Açısından İçerik Analizi. Ticaret ve Turizm Eğitim Fakültesi Dergisi, 1, 133-149.

16. Kozak, M. A. ve Yetgin, D. (2013). Profesyonel Turist Rehberlerinin (PTR) Yetkinliklerinin Mesleki Yeterlilikler Çerçevesinde Değerlendirilmesi, 14. Ulusal Turizm Kongresi, Erciyes Üniversitesi, Nevşehir, 5-8 Aralık: 408-428.

17. Köroğlu, Ö. (2013). Turist Rehberlerinin İş Yaşamındaki Rolleri Üzerine Kavramsal bir Değerlendirme. Pamukkale Üniversitesi Sosyal Bilimler Enstitüsü Dergisi, 16, 91-112.

18. Kurtuluş, K. (1996). Pazarlama Araştırmaları. 5. bask1, İstanbul: İÜ İşletme Fak. Yayını, No:28.

19. Kristensen, T.S., Borritz, M., Villadsen, E. \& Christensen, K.B. (2005). The Copenhagen burnout inventory: a new tool for the assessment of burnout. Work \& Stress, 19(3), 192-207.

20. Mak, A., Wong, K. ve Chang, R. (2011). Critical Issues Affecting the Service Quality and Professionalism of the Tour Guides in Hong Kong and Macau. Tourism Management, 32 (6), 1442-1452.

21. Maslach, C. (1982). Burnout: the cost of caring. Englewood Cliffs, New Jersey: Prentice Hall.

22. Maslach, C. \& Leiter, M.P. (1997). The truth about burnout: how organizations cause personal stress and what to do about it. San Francisco: Jossey-Bass.

23. Muijs, D. (2004). Doing quantitative research in education with spss. CA: Sage Publications.

24. Nardi, P.M. (2003). Doing survey research, a guide to quantitative methods. MA: Allyn and Bacon.

25. Özdamar, K. (2002). Paket Programlar İle İstatistiksel Veri Analizi. Eskişehir: Kaan Kitapevi

26. Pines, A. \& Maslach, C. (1980). Combating staff burn-out in a day care center: a case study. Child Care Quarterly, 9, 5-16.

27. Pond, K.L. (1993). The Professional Guide. New York: Van Nostrand Reinhold.

28. Schaufeli, W. B., \& Enzmann, D. (1998). The burnout companion to study and practice: A critical analysis. London: Taylor \& Francis.

29. Shirom, A. (1989). Burnout in work organizations. In C.L. Cooper \& I. Robertson (Eds.), International review of industrial and organizational psychology (pp. 25-48). New York: Wiley.

30. Shirom, A. (2003). Job related burnout: a review. In J.C. Quick \& L.E. Tetrick (Eds.), Handbook of occupational health psychology (pp. 245-264).

Washington, DC: American Psychological Association.

31. Tetik, N. (2015). Turist Rehberlerinin Davranışsal Personel Güçlendirme Algıları. Işletme Araştırmaları Dergisi, 7(3), 407-431. 
32. Tosun, C. ve Temizkan, R. (2004). Türkiye'nin Dış Tanıtım ve Ülke İmajında Turist Rehberlerinin Rolü. 1. Balıkesir Ulusal Turizm Kongresi. Balıkesir: Balıkesir Üniversitesi. 345-365.

33. UNWTO.(2016). UNWTO Tourism Highlights, 2015 Edition. Madrid: United Nations World Tourism Organization (UNWTO). [URL: http://mkt.unwto.org/publication/unwto-tourism-highlights-2015-edition] (Access: 10.02.2016).

34. Vogt, W.P. (2007). Quantitative research methods for professionals. New York: Pearson Education Inc.

35. Weiermair, K. \& Bieger, T. (2005). Tourism education in Austria and Switzerland, Journal of Teaching in Travel \& Tourism, 5 (1-2), 39-60. doi:10.1300/J172v05n01 03

36. WFTGA.(2015).World Federation of Tourist Guide Associations. [URL: http://www.wftga.org/tourist-guiding/what-tourist-guide] (Access: 10.11.2015).

37. Yarcan, Ş. (2007).Profesyonel Turist Rehberliğinde Mesleki Etik Üzerine Kavramsal Bir Değerlendirme. Anatolia: Turizm Araştırmaları Dergisi, 18 (1), 3344.

38. Yazıcıoğlu, İ., Tokmak, C. ve Uzun, S. (2008). Turist rehberlerinin rehberlik mesleğine bakışı, Üniversite ve Toplum Dergisi, 8 (2), http://www.universitetoplum.org/text.php3?id=367, (Access: 26.08.2016). 